International Journal of Agriculture, Environment and Bioresearch

Vol. 5, No. 02; 2020

ISSN: $2456-8643$

\title{
GENETIC POLYMORPHISM OF ABCG2 AND DGAT1 GENES IN WHITE FULANI AND MUTURU CATTLE BREEDS
}

\author{
Ridwan O. Ahmed ${ }^{1}$, Semiu. F. Bello ${ }^{2}$, Moibi O. Adeyemi ${ }^{3}$, and Umar-Faruq O. Bolaji ${ }^{4}$ \\ ${ }^{1}$ Institute of Biological, Environmental and Rural Science, Aberystwyth University, UK. \\ ${ }^{2}$ Department of Animal Genetics, Breeding and Reproduction, College of Animal Science, South China Agricultural \\ University, PR China. \\ ${ }^{3}$ Department of Animal Breeding and Genetics, Federal University of Agriculture, Abeokuta, Nigeria. \\ ${ }^{4}$ Animal Breeding and Genetics Unit, Department of Animal Science, University of Ibadan, Nigeria.
}

https://doi.org/10.35410/IJAEB.2020.5496

\begin{abstract}
Constant improvement of desirable traits is the key to a sustainable animal production and marker-assisted selection is pivotal to achieving this aim. Marker-assisted selection guides farmers by taking advantage of genetic variations within candidate genes that influence production traits in the animals. One of such desirable traits is milk production. ATP-binding cassette sub-family $\mathrm{G}$ member 2 (ABCG2) protein is involved in the transport of xenobiotics and other nutrients such as cholesterol from the blood into the milk. Diacylglycerol acyltransferase (DGAT1) plays a crucial role in regulating the rate of synthesis of triacylglycerides in fat cells such as those in the mammary gland. Previous researches have reported association between these genes and milk production traits in cattle. In this study, we examined polymorphisms in the variable regions of these candidate genes in Africa's White Fulani and Muturu cattle breeds. The results revealed three variants, KK, AK and AA for DGAT1 exon 8. The KK genotype predominates in both breeds with a frequency of $83 \%$ and $60 \%$ in White Fulani and Muturu, respectively. All sampled animals in both breeds were monomorphic at the ABCG2 exon 14 .
\end{abstract}

Keywords: Marker-assisted selection, White Fulani, Muturu, Polymorphism, ABCG2, DGAT1.

\section{INTRODUCTION}

Cattle production is a key component of agriculture in Nigeria. It represents a means of livelihood for the small-scale rural cattle owners and those involved in the cattle production value chain [1]. Income is generated both directly from beef and dairy products, and indirectly via secondary outputs like manure generation, leather production, and draught power [2[. Cattle also serves as a valuable source of protein to the people. It is generally believed that Nigerian cattle breeds is still producing far below their genetic potential [3]. To improve physical traits such as milk production and growth rate, it is expedient for genomic selection to be incorporated in the current breeding practices. These physical traits are controlled by an interplay of genes which determines variation in productivity observed between individual cattle. Candidate gene approach is one of the common methods used to identify genetic variation contributing to the 
observed physical differences in production traits. Certain genes have been reported in the literature as affecting milk production traits.

$A B C G 2$ encodes for ATP-binding cassette sub-family $\mathrm{G}$ member 2 protein. This protein is involved in the transport of xenobiotics and other nutrients such as cholesterol from the blood into the milk [4]. It is highly expressed during lactation and less expressed during the dry period. The gene is located on bovine chromosome 6 , and its polymorphisms have been confirmed by several research works to affect milk production traits. Many studies focused on the single nucleotide polymorphism $(\mathrm{A} / \mathrm{C})$ on exon 14, which results in amino acid substitution, tyrosine to serine (Y581S) [5]. Animals with ABCG2-A allele of the polymorphism had decreased milk yield but increased milk protein and fat composition in Israeli Holstein-Friesians [5]. This is an economically desirable trait desired for selection in dairy cattle breeding programs [6].

Cattle genome and linkage mapping revealed that acyl CoA: diacylglycerol acyltransferase (DGAT1) gene is a candidate gene for milk production traits [7]; [8]. DGAT1 was mapped to the centromeric end of bovine chromosome 14. DGAT1 plays a crucial role in regulating the rate of synthesis of triacylglycerides in fat cells [9]. Variation in milk yield and composition are observed when a mutation in the gene causes the replacement of lysine by alanine (K232A) in the amino acid profile. [7] reported that DGTA1-k, which is the ancestral allele, caused a $0.34 \%$, $0.08 \%$ and $10.46 \mathrm{~kg}$ increase in milk fat, milk protein, and fat yield respectively, and a reduction of $316 \mathrm{~kg}$ and $10.46 \mathrm{~kg}$ in milk yield and protein yield respectively, when compared to the DGTA1-A allele. [10]characterized DGAT1 polymorphism in 1748 cattle belonging to different breeds of the Bos taurus and Bos indicus origin, and of different selections - Dairy, Beef, and mixed breed. PCR-RFLP (CfrIrestriction enzyme) was used to genotype the AAG>GCG polymorphism on exon 8 of DGATl. Their results showed that the Bos indicus breeds have lowest divergence from the ancestral allele.

In this study, we investigated polymorphisms of $A B C G 2$ and $D G A T 1$ genes in White Fulani and Muturu cattle breeds of Nigeria. The White Fulani, a Bos indicus, is regarded as the most numerous and widespread Nigerian cattle breed representing 37\% of the country's herd [11]. They are regarded to have the highest milk yield of all indigenous cattle breeds in the country producing up to2,300 $\mathrm{kg}$ of milk per lactation [12]. TheMuturu, a West African taurine, is a small-bodied trypanotolerant cattle [13]. They are poor-milkers with milk yield of $127-421 \mathrm{~kg}$ reported over a lactation duration of 120-216 days [14];[15].

\section{METHODS}

\section{Data collection and Animal source}

Forty adult cattle (between the ages of 19-24 months) each of Muturu and White Fulani breed were randomly selected from different livestock owners, to be as distantly related as possible. The cattle were reared under a semi-intensive system. Muturu and White Fulani were sourced from Ipokia Local Government Area, Ogun state and Oyo West Local Government Area, Oyo state, Nigeria, respectively. Using the PG-100 collection kit from PERFORMAGENE, nasal swab was collected from each animal for DNA extraction. 
Vol. 5, No. 02; 2020

ISSN: $2456-8643$

\section{Genomic DNA extraction}

Genomic DNA was extracted from the nasal swabs following PERFORMAGENE guidelines found on https://www.dnagenotek.com/US/pdf/PD-PR-083.pdf).

\section{PCR amplification}

For the two genes considered in this study, primers listed in the literature to amplify desired gene regions were ordered. Amplified regions and the expected SNP within each gene region, as reported in the literature, are presented in Table 1 . The primers were first mixed with their respective quantities of 1 xTE buffer to make it up to $100 \mu \mathrm{M}$ as prescribed the primer-design company. The forward and reverse primers were then mixed and diluted with double-distilled water (ddH20) to make 1:10 primer-mixture dilution - $80 \mu \mathrm{L}$ ddH20 and $10 \mu$ Leach of forward and reverse primer.

Polymerase chain reaction (PCR) was performed in a $15 \mu \mathrm{L}$ reaction mixture that contained $2 \mu \mathrm{l}$ genomic DNA, $1 \mu \mathrm{L}$ of primer mix, $7.5 \mu \mathrm{L}$ PCR ImmoMix (contained magnesium chloride, DNA polymerase, and dNTP - Bioline Ltd, UK) and 4.5 $\mu \mathrm{L}$ ddH2O. The PCR cycling was performed in a G-Storm GS1 thermal cycler (Akribis Scientific limited, UK) with the following general protocols: $98^{\circ} \mathrm{C}$ for 10 mins (initial denaturation), followed by 35 cycles of denaturation at $98^{\circ} \mathrm{C}$ for $30 \mathrm{~s}, 50^{\circ} \mathrm{C}$ annealing for $30 \mathrm{~s}$, and a final extension at $72^{\circ} \mathrm{C}$ for $60 \mathrm{~s}$. The actual annealing temperature used for amplifying each gene region is presented in Table 1.

Table 1. Primers used to amplify the target regions of each gene

\begin{tabular}{|c|c|c|c|c|c|}
\hline Gene & Target region & SNP(s) & Primers & A.T 1 & Ref \\
\hline$A B C G 2$ & Exon 14 & $\mathrm{~A} / \mathrm{C}$ & F: AACAGCCTCAGCTCCAGAGAGATAT & 50 & [5] \\
\hline & & & R: CGGTGAAGATAAGGAGAACATACT & & - \\
\hline DGAT1 & Exon 8 & K232A & $\begin{array}{l}\text { F: CTTGCTCGTAGCTTTGGCAGG } \\
\text { R: CGAAGAGGAAGTAGTAGAGATC }\end{array}$ & 50 & {$[16]$} \\
\hline
\end{tabular}

A.T: Annealing temperature in ${ }^{\circ} \mathrm{C}$, Ref: Reference

\section{Agarose Gel Electrophoresis}

PCR products were detected by electrophoresis using $1 \%$ agarose gel containing a mixture of $150 \mathrm{ml}$ of 1XTAE(Tris/Acetate/EDTA) buffer, $1.5 \mathrm{~g}$ agarose, and $2 \mu 1$ GelRed. For each sample, $10 \mu \mathrm{L}$ mixture containing $3 \mu \mathrm{l}$ PCR product and $7 \mu \mathrm{L}$ loading buffer, was loaded on the gel plate. 
Vol. 5, No. 02; 2020

ISSN: $2456-8643$

\section{Genotyping by PCR-Restriction Fragment Length Polymorphism}

$A B C G 2$ exon 14 amplicon was genotyped by restriction fragment length polymorphism (RFLP) using Pst1 restriction enzyme (New England, Biolabs). The digestion mixture- which contained aliquots of $5 \mu 1 \mathrm{PCR}$ product, $0.5 \mu \mathrm{L}$ restriction enzyme, $2 \mu \mathrm{L}$ cutsmart buffer, and $12.5 \mu \mathrm{L} \mathrm{ddH}_{2} 0$ was incubated overnight at $37^{\circ} \mathrm{C}$. Digested products were electrophoresed on $2 \%$ agarose gel following the same procedure described above, except that the quantity of agarose was 3 grams.

\section{Amplicon clean up}

PCR product from $D G A T 1$ exon 8 to be directly sequenced was first purified so that the primers and buffers were removed, leaving behind pure DNA. $60 \mu \mathrm{L}$ of ethanol/NaOA csolution $(9375$ $\mu 1100 \%$ ethanol, $450 \mu \mathrm{L} 3 \mathrm{M}$ sodium acetate and $2175 \mu \mathrm{L}$ of ddH20) was added to the $15 \mu \mathrm{L}$ PCR product. The mixture was left for $15 \mathrm{mins}$ to allow for DNA precipitation, after which it was centrifuged for $45 \mathrm{mins}$ at $2500 \mathrm{RCF}$. At this point, DNA had been precipitated, and the PCR plate was inverted in a centrifuge for 5 seconds to remove the solution containing primers and buffer. To remove any leftover primer, $75 \mu \mathrm{L}$ of $80 \%$ ethanol was added to each sample, centrifuged for 5 mins and inverted to remove the solution, leaving behind pure DNA. The purified DNA was diluted with $13 \mu \mathrm{L}$ ddH 20 .

\section{DNA sequencing}

$5 \mu \mathrm{L}$ of the purified DNA sample for DGAT1 exon 8 was mixed with $2 \mu \mathrm{L}$ of diluted (1:50) forward primer. After this, it was sent for Sanger sequencing at the Institute of Biological, Environmental and Rural Science (IBERS) sequencing facility at Aberystwyth University, UK.

\section{Sequence alignment}

The sequence reads generated were search against the NCBI/Gen Bank database using BLAST to check the percentage identity with the gene of interest. Using Genomic Workbench software (version 6.5), multiple alignments of sequence reads from all samples was constructed to evaluate base constitution on each position and for subsequent SNP identification. The software was also used to trim low-quality reads. Base positions represented by multiple reads were identified as candidate polymorphic sites. The base-callings cores at the polymorphic sites and the number of times each base variant (allele) appeared inthe samples were checked to increase confidence that the sequence variant is a true mutation, and not merely sequence error. Geneious software (version 2019.2) [17]was used to alignmultiple chromatograms to check for homozygosity and heterozygosity at the mutation sitesbased on the presence of double peaks at the SNP site.

\section{Data Analyses}

Allelic and genotypic frequencies for each SNP were calculated by direct counting. The genotypic frequencies were tested for deviation from Hardy-Weinberg equilibrium using Chisquare $(\chi 2)$ analysis. 


\section{RESULTS}

\section{ABCG2 gene polymorphism}

Figure 1 shows the un-cut digest product for $A B C G 2$ exon 14. In both the White Fulani and Muturu cattle population, all sample animals were monomorphic retaining the 292 base pair length of the PCR product (AA genotype).

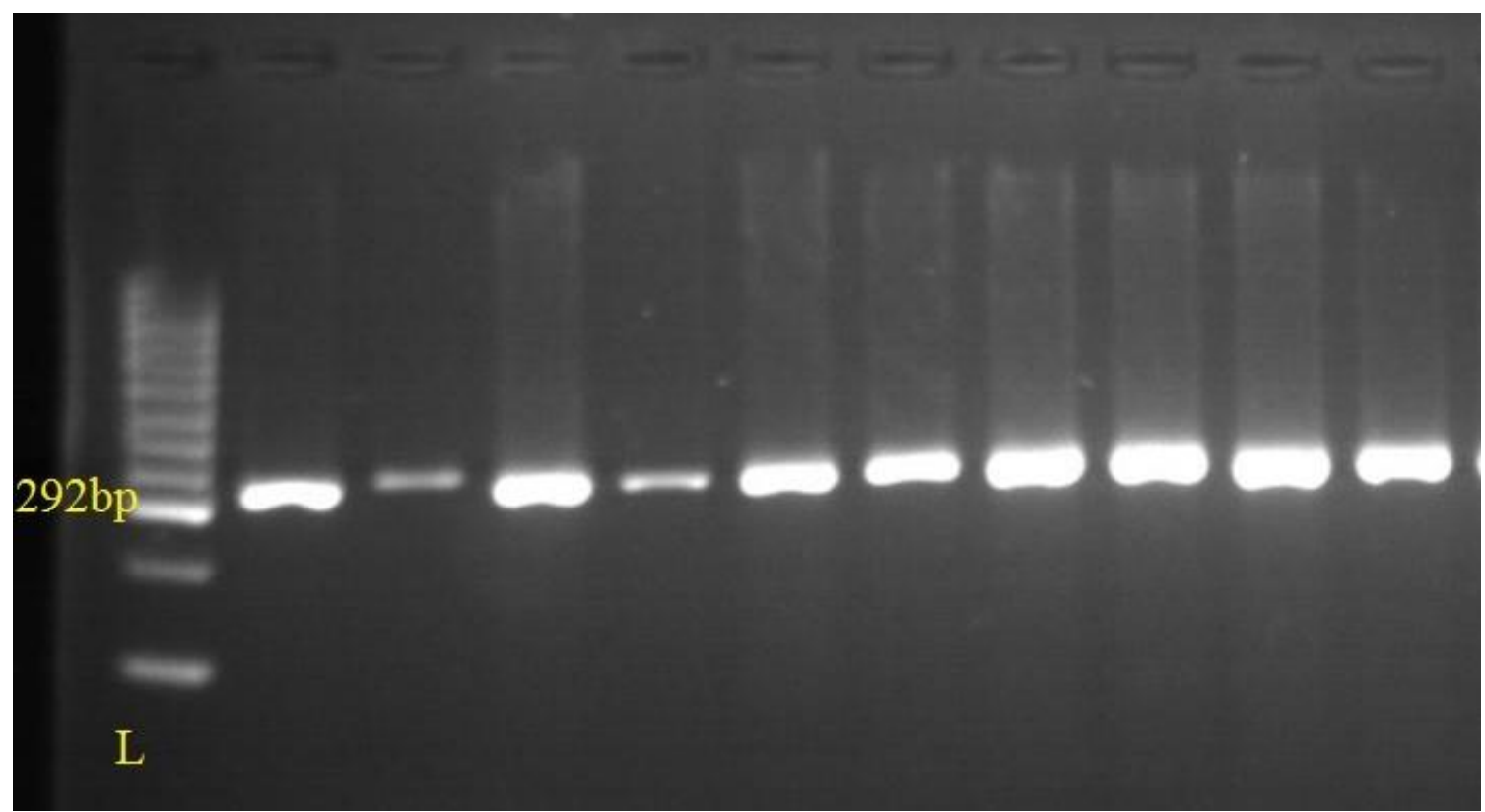

Figure 1. Gel image for $A B C G 2$ exon 14 un-cut digest product. $\mathrm{L}=$ Ladder

\section{DGAT1 gene polymorphism}

176-bp fragment in the exon 8 of the acyl-CoA: diacylglycerol acyltransferase-1 (DGAT1) gene was amplified; a region that contained the K232A substitution. The amplicon was sequenced for 80 cattle. Geneious Prime software (version 2019.2) was used for sequence mapping and alignment. Allelic and genotypic frequencies in each breed were determined by direct counting. Haplotype GC and AA represents A and K-alleles respectively (Figure 2) 
Vol. 5, No. 02; 2020

ISSN: $2456-8643$
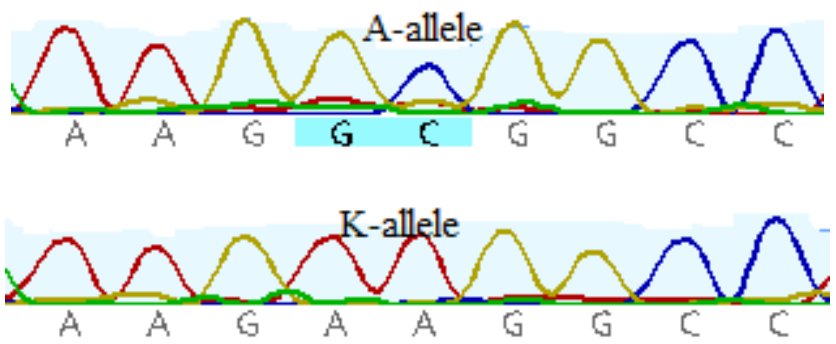

Figure 2 Sequence map showing K232A mutation in DGAT1

In both breeds, the K-allele predominates. However, it is observed that A-allele occurred more frequently in Muturu ( 30\%) compared to $10 \%$ in White Fulani (Table 2).Genotypic frequencies in White Fulani agreed with Hardy-Weinberg equilibrium $(\mathrm{P}>0.05)$ while those of Muturu deviated from Hardy-Weinberg equilibrium $(\mathrm{P}<0.05)$.

Table 2. Allelic and genotypic frequencies of DGAT1 K232Apolymorphisms in Muturu and White Fulani cattle.

\begin{tabular}{lcclclllll}
\hline Breed & \multicolumn{3}{c}{ Genotypic freq. } & Total & \multicolumn{2}{c}{ Allele freq. } & \multicolumn{2}{c}{$\operatorname{HWE}\left(\chi^{2}\right)$} & P-value \\
\hline & KK & AK & AA & & K & A & & \\
WF & $0.83(33)$ & $0.14(6)$ & $0.03(1)$ & 40 & 0.90 & 0.10 & 0.174 & 0.917 \\
MUT & $0.60(24)$ & $0.23(9)$ & $0.17(7)$ & 40 & 0.71 & 0.29 & 6.113 & 0.047 \\
\hline
\end{tabular}

\section{DISCUSSION}

\section{ABCG2 polymorphism in White Fulani and Muturu cattle}

PCR-RFLP using Pstlenzyme produced uncut products in all Muturu and White Fulani cattle samples considered in this study. This showed that all the animals were monomorphic for the AA genotype (frequency of 1.0). Heterozygous AC and CC genotype were completely absent. This result agrees with the findings of [18] who also reported zero frequencies for $\mathrm{AC}$ and $\mathrm{CC}$ genotype in Sahiwal and Hariana cattle breeds. Also,[19] reported complete absence of ABCG-C allele in three zebu breeds, including White Fulani. Plausible explanation by [19] was that the complete absence of $A B C G 2-\mathrm{C}$ allele in the zebu breeds might indicate that $A B C G 2-\mathrm{A}$ is an ancestral allele, and the polymorphism only occurred after segregation of the zebu and Bos taurus lineage. This might not hold true, as Muturu, a taurine breed, is also monomorphic for the polymorphism. Although the $A B C G 2-\mathrm{A}$ allele was found in other studies, monomorphic tendencies for in the $\mathrm{A}>\mathrm{C}$ polymorphism in $\mathrm{ABCG} 2$ exon 14 has been reported. $A B C G-\mathrm{A}$ and $A B C G 2-C$ allelic frequencies were 0.80 and 0.20 respectively in Jersey cattle breed [20] and 0.99 and 0.01 in Holstein bulls [5]. Contrary to the findings of the above listed authors, [22] reported 
0.65 and 0.35 as allelic frequencies for A and C respectively, in Turkey's South Anatolian Red and East Anatolian Red cattle breeds.

$A B C G 2$ has been suggested to influence the transport of cholesterol into milk [5]. No association with milk-related traits can be inferred from this study as all the animals were of the same genotype, and because milk production data was not collected. Association studies by [5] and [23] have revealed that the $A B C G 2$-A allele is favourable for increased milk protein and milk fat percentages, but a lowered milk yield. On the other hand, selection for $A B C G-\mathrm{C}$ allele has a negative effect on milk protein and milk fat percentages. In line with this, [24] showed that White Fulani cattle, despite producing comparatively lesser milk yield, had higher milk fat percentage (5.72 vs 4.40) when compared to Friesian cattle.

\section{DGAT1 polymorphism in White Fulani and Muturu cattle}

K-allele of the K232A polymorphism predominates in both breeds; $90 \%$ in White Fulani and $71 \%$ in Muturu. The higher relative occurrence of the A-allele in Muturu was typified by the $17 \%$ frequency of the AA genotype in comparison to 3\% in White Fulani. This divergence in the occurrence of A-allele in the two African breeds might be connected to their varied origin- White Fulani is zebu while Muturu is an indicine breed. This position has been supported by many research outcomes that indicated that zebu breeds have a very low divergence for the K232A polymorphism [25]-[28]. [25] compared K232A polymorphism in Bos taurus and Bos indicus cattle and revealed that A-allele was of very low frequency in Bos indicus cattle breeds. Among the cattle breed used for the study were White Fulani and N'Dama African breed. 92\% of the White Fulani cattle had K-allele in that population. This is comparable to the $97 \%$ occurrence of A-allele in White Fulani population used in the present study. The N'Dama breed, which is an African taurine just like Muturu, had 48\% DGAT1-A allele in the study of [25] Taking that result into consideration, it is not surprising that Muturu breed in this present study had 20\% DGATI-A allele frequency. All Indian Bos indicus cattle breeds examined by [26] retained the DGATI-K allele. The same pattern of result was reported by [28] where Korean Bos indicus cattle (Hanwoo) had $75 \%$ and $25 \%$ allele frequencies for DGATI-K and-A alleles, respectively.

Several studies have associated DGAT1-K232A polymorphism with milk production traits. $D G A T 1$ enzyme regulates the rate of synthesis of triacyl-glycerides in fat cells [29]. The AA $>$ GC mutation causes a non-synonymous lysine to alanine substitution in the DGAT1 protein amino acid sequence. [30] reported that DGTAl-K, which is the ancestral allele, caused a $0.34 \%, 0.08 \%$ and $10.46 \mathrm{~kg}$ increase in milk fat, milk protein, and fat yield respectively, and a reduction of $316 \mathrm{~kg}$ and $10.46 \mathrm{~kg}$ in milk yield and protein yield respectively, when compared to the DGTA1-A allele. It is generally believed that the K-variant is associated with increased milk fat content while the A-variant lowers fat content of milk but increases milk protein and milk yield [31][33]. Cattle with K-allele synthesized over 1.5x triglyceride than those with K-allele [34]. It has been documented that White Fulani, which has more of the DGAT1-K allele produced more milk fat content in comparison to Muturu[35]. Association study with milk production traits was not done in this study due to time and cost constraints. However, the interesting and varied allelic distribution between the two breeds obtained in this study provides useful information for further studies with the aim of marker-assisted selection. 
Vol. 5, No. 02; 2020

ISSN: $2456-8643$

\section{CONCLUSION}

Previous researchers have identified genes and genetic regions associated with productivity traits in cattle. In this study, we investigated, in White Fulani and Muturu cattle breeds, polymorphisms in two candidate genes- $A B C G 2$ and $D G A T 1$ that have been reported to influence milk production traits in cattle. All animals were monomorphic at the ABCG2 exon 14 while three genotypes were identified for the $D G A T 1$ gene. Further research will be needed to validate the absence of polymorphism in the $A B C G 2$ and it will be useful to examine the association of $D G A T 1$ variants with milk production.

\section{Authors Contribution}

Ridwan Olawale Ahmed designed the experiment, carried out laboratory works, did the statistical analysis and wrote the manuscript. SemiuFola Bello, Moibi Oluwatosin Adeyemi and Umar-Faruq O. Bolaji collected field data- collection of nasal swabs from cattle. All authors read and approved the manuscript.

\section{REFERENCES}

[1] Okunmadewa, F. (1999). Livestock industry as a tool for poverty allevation. Nigerian Journal of Animal Science, 2(2).

[2] Mapiye, C., Chimonyo, M., Dzama, K., Raats, J. G., \&Mapekula, M. (2009). Opportunities for improving Nguni cattle production in the smallholder farming systems of South Africa. Livestock Science, 124(1-3), 196-204.

[3] Lawal, A. T., Mohammed, A. B., \& Musa, S. A. (2016). Hedonic Price Analysis of Characteristics Influencing Cattle Prices in Ngalda Livestock Markets in Yobe State. Journal of Agriculture and Sustainability, 9(1).

[4] Jonker, J. W., Merino, G., Musters, S., van Herwaarden, A. E., Bolscher, E., Wagenaar, E., ... \& Schinkel, A. H. (2005). The breast cancer resistance protein BCRP (ABCG2) concentrates drugs and carcinogenic xenotoxins into milk. Nature medicine, 11(2), 127.

[5] Cohen-Zinder, M., Seroussi, E., Larkin, D. M., Loor, J. J., Everts-Van Der Wind, A., Lee, J. H., \& Lewin, H. A. (2005). Identification of a missense mutation in the bovine ABCG2 gene with a major effect on the QTL on chromosome 6 affecting milk yield and composition in Holstein cattle. Genome research, 15(7), 936-944.

[6] Miglior, F., Muir, B. L., \& Van Doormaal, B. J. (2005). Selection indices in Holstein cattle of various countries. Journal of dairy science, 88(3), 1255-1263.

[7] Grisart, B., Coppieters, W., Farnir, F., Karim, L., Ford, C., Berzi, P., \& Spelman, R. (2002). Positional candidate cloning of a QTL in dairy cattle: identification of a missense mutation in the bovine DGAT1 gene with major effect on milk yield and composition. Genome research, 12(2), 222-231.

[8] Winter, A., Krämer, W., Werner, F. A., Kollers, S., Kata, S., Durstewitz, G., \& Fries, R. (2002). Association of a lysine-232/alanine polymorphism in a bovine gene encoding acylCoA: diacylglycerol acyltransferase (DGAT1) with variation at a quantitative trait locus for milk fat content. Proceedings of the National Academy of Sciences, 99(14), 9300-9305.

[9] Lehner, R., \&Kuksis, A. (1996). Biosynthesis of triacylglycerols. Progress in lipid research, 35(2), 169-201. 
[10] Kaupe, B., Winter, A., Fries, R., \& Erhardt, G. (2004). DGAT1 polymorphism in Bos indicus and Bos taurus cattle breeds. Journal of dairy research, 71(2), 182-187.

[11] Alphonsus, C., Akpa, G. N., \&Barje, P. P. (2012). Comparative evaluation of linear udder and body conformation traits of bunaji and friesian x bunajicowsWorld. J Life Sci Medical Res 2 (4): 134-140.

[12] Kubkomana, H. I. (2017). Indigenous breeds of cattle, their productivity, economic and cultural values in sub-saharan Africa: A review. International Journal of Research studies in Agricultural Sciences, 3(1), 27-43.

[13] Maule, J. P. (1990). The cattle of the tropics. University of Edinburgh Centre for Tropical Veterinary Medicine, Edinburgh, UK. ISBN: 9907146058.

[14] Olaloku, E. A. (1976). Milk production in West Africa: objective and research approaches. J. Ass. Adv. Agric. Sci. Africa (AAASA)3, 5-13.

[15] Fricke, W. (1979). Cattle husbandry in Nigeria: a study of its ecological conditions and social-geographical differentiations.(Pp 330).Geographische Inst. der Universitat Heidelberg, Heidelberg, Germany.

[16] Ripoli, M. V., Corva, P., \&Giovambattista, G. (2006). Analysis of a polymorphism in the DGAT1 gene in 14 cattle breeds through PCR-SSCP methods. Research in veterinary science, 80(3), 287-290.

[17] Kearse, M., Moir, R., Wilson, A., Stones-Havas, S., Cheung, M., Sturrock, S., ... and Thierer, T. (2012). Geneious Basic: an integrated and extendable desktop software platform for the organization and analysis of sequence data. Bioinformatics, 28(12), 1647-1649. Available from https://academic.oup.com/bioinformatics/article/28/12/1647/267326 [Accessed on 10 March 2020]

[18] Sharma, A., Tiwari, M., Singh, S. P., Sharma, D., Kumar, S., Sharma, A., \& Verma, A. K. (2016). Study of ABCG2 gene polymorphism in Sahiwal and Hariana Cattle by PstI/PCRRFLP assay. Journal of Animal Research, 6(3), 475-477.

[19] Ron, M., Cohen-Zinder, M., Peter, C., Weller, J. I., \& Erhardt, G. (2006). A polymorphism in ABCG2 in Bos indicus and Bos taurus cattle breeds. Journal of dairy science, 89(12), 4921-4923.

[20] Kowalewska-Łuczak, I. N. G. A., Kulig, H., \&Kmieć, M. A. R. E. K. (2009). Amplification created restriction sites for genotyping SNP in the bovine ABCG2 and its association with milk production traits (Brief Report). Archives Animal Breeding, 52(6), 647649.

[21] Cohen-Zinder, M., Seroussi, E., Larkin, D. M., Loor, J. J., Everts-Van Der Wind, A., Lee, J. H., \& Lewin, H. A. (2005). Identification of a missense mutation in the bovine ABCG2 gene with a major effect on the QTL on chromosome 6 affecting milk yield and composition in Holstein cattle. Genome research, 15(7), 936-944.

[22] Ateş, A., Hoştürk, G. T., Akiş, I., Gürsel, F. E., Yardibi, H., \&Öztabak, K. (2014). Genotype and allele frequencies of polymorphisms in ABCG2, PPARGC1A and OLR1 genes in indigenous cattle breeds in Turkey. Acta veterinaria, 64(1), 73-80.

[23] Olsen, H. G., Nilsen, H., Hayes, B., Berg, P. R., Svendsen, M., Lien, S., \&Meuwissen, T. (2007). Genetic support for a quantitative trait nucleotide in the ABCG2 gene affecting milk composition of dairy cattle. BMC genetics, $8(1), 32$. 
[24] Sohael, A. S. "Milk production potential of cattle on the Jos Plateau." Nigeria Livest. Earner 4.3 (1984): 13-14.

[25] Kaupe, B., Winter, A., Fries, R., \& Erhardt, G. (2004). DGAT1 polymorphism in Bos indicus and Bos taurus cattle breeds. Journal of dairy research, 71(2), 182-187.

[26] Tantia, M. S., Vijh, R. K., Mishra, B. P., Mishra, B., Kumar, S. B., \& Sodhi, M. (2006). DGAT1 and ABCG2 polymorphism in Indian cattle (Bos indicus) and buffalo (Bubalusbubalis) breeds. BMC Veterinary Research, 2(1), 32.

[27] Lacorte, G. A., Machado, M. A., Martinez, M. L., Campos, A. L., Maciel, R. P., Verneque, R. S., \& Fonseca, C. G. (2006). DGAT1 K232A polymorphism in Brazilian cattle breeds. Genet Mol Res, 5(3), 475-482.

[28] Kong, H. S., Oh, J. D., Lee, J. H., Yoon, D. H., Choi, Y. H., Cho, B. W., \& Jeon, G. J. (2007). Association of sequence variations in DGAT 1 gene with economic traits in Hanwoo (Korea cattle). Asian-australasian journal of animal sciences, 20(6), 817-820.

[29] Lehner, R., \&Kuksis, A. (1996). Biosynthesis of triacylglycerols. Progress in lipid research, 35(2), 169-201.

[30] Grisart, B., Coppieters, W., Farnir, F., Karim, L., Ford, C., Berzi, P., \& Spelman, R. (2002). Positional candidate cloning of a QTL in dairy cattle: identification of a missense mutation in the bovine DGAT1 gene with major effect on milk yield and composition. Genome research, 12(2), 222-231.

[31] Spelman, R. J., Ford, C. A., McElhinney, P., Gregory, G. C., \& Snell, R. G. (2002). Characterization of the DGAT1 gene in the New Zealand dairy population. Journal of Dairy Science, 85(12), 3514-3517.

[32] Thaller, G., Kramer, W., Winter, A., Kaupe, B., Erhardt, G., \& Fries, R. (2003). Effects of DGAT1 variants on milk production traits in German cattle breeds. Journal of animal science, 81(8), 1911-1918.

[33] Weller, J. I., Golik, M., Seroussi, E., Ezra, E., \& Ron, M. (2003). Population-wide analysis of a QTL affecting milk-fat production in the Israeli Holstein population. Journal of Dairy Science, 86(6), 2219-2227.

[34] Grisart, B., Farnir, F., Karim, L., Cambisano, N., Kim, J. J., Kvasz, A.,\& Georges, M. (2004). Genetic and functional confirmation of the causality of the DGAT1 K232A quantitative trait nucleotide in affecting milk yield and composition. Proceedings of the National Academy of Sciences, 101(8), 2398-2403.

[35] Tayo, O. G; Anaeto, M. \&Adurogbangba, E. A (2005). Comparative composition of white Fulani and Muturu cows' milk. acta SATECH 2(2), $46-49$ 